\author{
R. Anzawa $\cdot$ M. Bernard $\cdot$ S. Tamareille $\cdot$ D. Baetz $\cdot$ \\ S. Confort-Gouny $\cdot$ J. P. Gascard $\cdot$ P. Cozzone $\cdot$ \\ D. Feuvray
}

\title{
Intracellular sodium increase and susceptibility to ischaemia in hearts from type 2 diabetic $\mathrm{db} / \mathrm{db}$ mice
}

Received: 8 June 2005 / Accepted: 19 October 2005 / Published online: 20 January 2006

(C) Springer-Verlag 2006

\begin{abstract}
Aims/hypothesis: An important determinant of sensitivity to ischaemia is altered ion homeostasis, especially disturbances in intracellular $\mathrm{Na}^{+}\left(\mathrm{Na}_{\mathrm{i}}^{+}\right)$handling. As no study has so far investigated this in type 2 diabetes, we examined susceptibility to ischaemia-reperfusion in isolated hearts from diabetic $d b / d b$ and control $d b /+$ mice and determined whether and to what extent the amount of $\mathrm{Na}_{\mathrm{i}}^{+}$increase during a transient period of ischaemia could contribute to functional alterations upon reperfusion. Methods: Isovolumic hearts were exposed to 30-min global ischaemia and then reperfused. ${ }^{23} \mathrm{Na}$ nuclear magnetic resonance (NMR) spectroscopy was used to monitor $\mathrm{Na}_{\mathrm{i}}^{+}$and ${ }^{31} \mathrm{P}$ NMR spectroscopy to monitor intracellular $\mathrm{pH}\left(\mathrm{pH}_{\mathrm{i}}\right)$. Results: A higher duration of ventricular tachycardia and the degeneration of ventricular tachycardia into ventricular fibrillation were observed upon reperfusion in $d b / d b$ hearts. The recovery of left ventricular developed pressure was reduced. The increase in $\mathrm{Na}_{i}^{+}$induced by ischaemia was higher in $d b / d b$ hearts than in control hearts, and the rate of $\mathrm{pH}_{\mathrm{i}}$ recovery was increased during reperfusion. The inhibition of $\mathrm{Na}^{+} / \mathrm{H}^{+}$exchange by cariporide significantly reduced $\mathrm{Na}_{i}^{+}$gain at the end of ischaemia. This was associated with a lower incidence of ventricular tachycardia in both heart groups, and with an inhibition of the degeneration of ventricular tachycardia
\end{abstract}

\footnotetext{
R. Anzawa · S. Tamareille $\cdot$ D. Baetz ·

J. P. Gascard · D. Feuvray $(\bowtie)$

UMR CNRS 8078, Université Paris-Sud XI,

Hôpital Marie Lannelongue,

133 avenue de la Résistance,

92350 Le Plessis Robinson, France

e-mail: danielle.feuvray@ibaic.u-psud.fr

Tel.: +33-1-40942521

Fax: +33-1-40942522

M. Bernard $\cdot$ S. Confort-Gouny $\cdot$ P. Cozzone

CNRS UMR 6612-CRMBM,

Faculté de Médecine,

Marseille, France

\section{R. Anzawa}

Division of Cardiology, Department of Internal Medicine, Jikei University School of Medicine,

Tokyo, Japan
}

into ventricular fibrillation in $d b / d b$ hearts. Conclusions/ interpretation: These findings strongly support the hypothesis that increased $\mathrm{Na}_{\mathrm{i}}^{+}$plays a causative role in the enhanced sensitivity to ischaemia observed in $d b / d b$ diabetic hearts.

Keywords Cardiac ischaemia-reperfusion $\cdot D b / d b$ mice Intracellular sodium - Type 2 diabetes .

Ventricular arrhythmias

Abbreviations $\mathrm{I}_{\mathrm{NaL}}$ : slowly inactivating component of $\mathrm{Na}^{+}$current - LVDP: left ventricular developed pressure . LVEDP: left ventricular end diastolic pressure $\cdot \mathrm{Na}_{i}^{+}$: intracellular sodium $\cdot \mathrm{NHE}: \mathrm{Na}^{+} / \mathrm{H}^{+}$exchange $\cdot \mathrm{NMR}$ : nuclear magnetic resonance $\cdot \mathrm{pH}_{\mathrm{i}}$ : intracellular $\mathrm{pH}$. $\operatorname{TmDOTP}^{5-}$ : thulium(III)-1,4,7,10-tetraazacyclododecane$N, N^{\mathrm{I}}, N^{\mathrm{II}}, N^{\mathrm{III}}$-tetra-(methylene phosphonate) $\cdot \mathrm{VF}$ : ventricular fibrillation - VT: ventricular tachycardia

\section{Introduction}

Several studies suggest that type 2 diabetes mellitus has direct adverse effects on the heart, independently of obstructive coronary artery disease [1]. Both clinical [2] and experimental [3] investigations have indeed pointed to a cardiomyopathy in humans producing abnormalities in ventricular function. However, relatively few experimental studies on the possible mechanisms of ventricular dysfunction have been performed in animal models of type 2 diabetes [4-6]. Diabetic $d b / d b$ mice provide an animal model of type 2 diabetes [7]. The natural progression of diabetes in $d b / d b$ mice, with initial insulin resistance followed by an insulin-secretion defect [8], is similar to the pathogenesis of type 2 diabetes in humans [9]. Recent studies using perfused working hearts from diabetic $d b / d b$ mice have demonstrated altered cardiac metabolism and reduced contractile performance $[5,6]$. Reduced cardiac function was also assessed in vivo in 12-week-old diabetic $d b / d b$ mice [10]. Impaired metabolism, i.e. increased fatty 
acid oxidation and decreased glucose utilisation, appeared to be an important causative factor in the contractile dysfunction $[5,6]$. To date, only a few investigators have reported results from ischaemia-reperfusion studies using $d b / d b$ hearts [6]. At 6 weeks, $d b / d b$ hearts showed normal recovery of contractile function following ischaemia, whereas at 12 weeks function was markedly reduced [6].

An important determinant of sensitivity to ischaemia is altered ion homeostasis, especially disturbances in intracellular $\mathrm{Na}^{+}\left(\mathrm{Na}_{\mathrm{i}}^{+}\right)$handling $[11,12]$. As no study has so far investigated this in type 2 diabetes and altered $\mathrm{Na}^{+}$ handling may indeed have functional as well as proarrhythmogenic consequences [13], we examined susceptibility to ischaemia-reperfusion in isolated hearts from 12- to 15-week-old $d b / d b$ mice and from age-matched control $d b /+$ mice, and determined whether and to what extent the amount of $\mathrm{Na}_{\mathrm{i}}^{+}$increase, monitored through ${ }^{23} \mathrm{Na}$ nuclear magnetic resonance (NMR) spectroscopy during a transient period of ischaemia, could contribute to functional alterations upon reperfusion. ${ }^{31} \mathrm{P}$ NMR spectroscopy was also used to monitor intracellular $\mathrm{pH}\left(\mathrm{pH}_{\mathrm{i}}\right)$, since the accumulation of $\mathrm{H}^{+}$, i.e. a decrease in $\mathrm{pH}_{\mathrm{i}}$ during severe ischaemia, is a promoting factor for the imbalance of other cations, especially $\mathrm{Na}^{+}$[14-16]. In addition, since it is known that $\mathrm{Na}^{+} / \mathrm{H}^{+}$exchange (NHE) contributes to $\mathrm{Na}^{+}$overload and that inhibitors of NHE exert substantial protection when present throughout ischaemia and reperfusion [16, 17], we compared the effects of NHE inhibition by cariporide in diabetic and control mouse hearts. A preliminary report on this study, in which $\mathrm{Na}_{\mathrm{i}}^{+}$ was non-invasively measured in the beating perfused mouse heart, has already been published [18].

\section{Materials and methods}

Experimental animals

Animals were cared for and used in accordance with the European convention for the protection of vertebrate animals used for experimental purposes, and institutional guidelines no. 86/609/CEE November 24, 1986. Male $\mathrm{C} 57 \mathrm{BL} / \mathrm{KsJ}$-leprdb/leprdb diabetic $(d b / d b)$ mice and their non-diabetic control littermates C57BL/KsJ-leprdb/lepr+ $(d b /+)$ were purchased from Janvier (Le Genest St. Isle, France). All animals used in this study were males between 12 and 15 weeks of age. The animals were housed in groups (five or six) and given free access to food and water.

\section{Heart perfusions}

Mice (fed dietary status) were anaesthetised with sodium pentobarbital $(100 \mathrm{mg} / \mathrm{kg}$ ) and heparinised (100 U) i.p. The heart was quickly removed and placed in ice-cold KrebsHenseleit bicarbonate buffer. After removing extraneous tissues, the aorta was cannulated with an 18-gauge steel cannula (in NMR study groups, with an 18-gauge plastic cannula). The heart underwent a Langendorff perfusion (80 $\mathrm{mmHg}$ perfusion pressure) with modified KrebsHenseleit bicarbonate perfusate, consisting of (mmol/l): $\mathrm{NaCl} 118, \mathrm{KCl} 5.9, \mathrm{MgSO}_{4} 1.2, \mathrm{NaHCO}_{3} 25, \mathrm{CaCl}_{2} 1.75$, EDTA 0.5, glucose 11, gassed with $95 \% \mathrm{O}_{2} / 5 \% \mathrm{CO}_{2}(\mathrm{pH}$ $\left.7.4,37^{\circ} \mathrm{C}\right)(20$-min stabilisation period) and was then immersed in a set volume of warmed perfusate $\left(37^{\circ} \mathrm{C}\right)$ so that coronary flow could be estimated by timed collection of coronary effluent. All perfusion solutions were filtered $(0.8 \mu \mathrm{m}$; Millipore) prior to use. Isovolumic left ventricular developed pressure (LVDP) was monitored using a fluidfilled polyvinylchloride film balloon inserted into the left ventricle via the mitral valve, and was connected to a Statham 23 ID pressure transducer. The initial left ventricular end diastolic pressure (LVEDP) was adjusted to 8$10 \mathrm{mmHg}$. LVDP was calculated by subtracting LVEDP from systolic pressure. Pressure signals were recorded on a Gould 2,200 recorder (Gould Instruments, Ballainvilliers, France) and IOX data acquisition system (EMKA Technologies, Paris, France). For all experiments, hearts were allowed to contract spontaneously. For ${ }^{23} \mathrm{Na}$ NMR measurements, we used the shift agent thulium(III)-1,4,7, 10 -tetraazacyclododecane- $N, N^{\mathrm{I}}, N^{\mathrm{I}}, N^{\mathrm{III}}$-tetra-(methylene phosphonate) (TmDOTP ${ }^{5-}$ ) (Macrocyclics, Dallas, TX, USA), as previously described [11]. TmDOTP ${ }^{5-}$ was dissolved in $\mathrm{H}_{2} \mathrm{O}$ and subsequently added to the perfusate to reach a concentration of $3.5 \mathrm{mmol} / 1$. Since TmDOTP ${ }^{5-}$ is a sodium salt that binds $\mathrm{Ca}^{2+}$ to a significant extent, both $\mathrm{Na}^{+}$and $\mathrm{Ca}^{2+}$ were corrected. $\mathrm{NaCl}$ was adjusted to keep the total $\mathrm{Na}^{+}$content unchanged, and the total $\mathrm{Ca}^{2+}$ content was increased to $3.42 \mathrm{mmol} / \mathrm{l}$, resulting in a free ionised $\mathrm{Ca}^{2+}$ of $0.85-0.95 \mathrm{mmol} / \mathrm{l}$, measured by using a $\mathrm{Ca}^{2+}$ ion-selective electrode (Orion).

\section{NMR spectroscopy}

The ${ }^{23} \mathrm{Na}$ and ${ }^{31} \mathrm{P}$ spectra were recorded on a spectrometer (AM 400 WB; Bruker BioSpin, Ettlingen, Germany) at 105.84 and $161.98 \mathrm{MHz}$, respectively, using a multinuclear NMR probe. The spectrometer was equipped with a $9.4 \mathrm{~T}$ vertical magnet and the perfused heart was inserted into a multinuclear 10-mm diameter glass NMR tube, in which the temperature was maintained at $37^{\circ} \mathrm{C}$. Magnetic field homogeneity was optimised using the ${ }^{1} \mathrm{H}$ resonance of $\mathrm{H}_{2} \mathrm{O}$. Each Na NMR spectrum (1-min time-resolved) was obtained by accumulation of 280 consecutive free induction decays using $90^{\circ}$ pulses and a $205-\mathrm{ms}$ interpulse delay with a $2,500-\mathrm{Hz}$ spectral width and a $1-\mathrm{k}$ data points time domain. ${ }^{23} \mathrm{Na}$ NMR spectra were processed for the quantitative analysis of the intracellular component $\mathrm{Na}_{i}^{+}$ in two steps. First, removal of the overlapping spectral extracellular component was carried out by the HLSVD method [19]. Second, the $\mathrm{Na}_{i}^{+}$peaks were quantified with a time domain fitting routine (AMARES) [20]. The $\mathrm{Na}^{+}$ 
resonance of a standard solution containing a fixed amount of $\mathrm{Na}^{+}$and $\mathrm{TmDOTP}^{5-}$ in a glass capillary was used for absolute quantification. Eighteen pre-ischaemic spectra were obtained followed by spectra collected over $30 \mathrm{~min}$ of ischaemia (30 spectra). $\mathrm{Na}^{+}$spectra were not collected during reperfusion because we found there to be a negative effect of the presence of $\mathrm{Na}^{+}$shift reagent on coronary flow rate at reperfusion (effect on coronary flow has been previously noted by others [21]), which appeared to be deleterious at reflow after severe ischaemia in the mouse heart. ${ }^{31} \mathrm{P}$ spectra were obtained from 288 free induction decays following $75^{\circ}$ pulses repeated every second using 4-k data points and a $6,000 \mathrm{~Hz}$ spectral width (5-min timeresolved spectra). To study changes in $\mathrm{pH}_{\mathrm{i}}$ during the early phase of reflow following ischaemia with greater time resolution, 1-min time-resolved spectra were acquired. Values for $\mathrm{pH}_{\mathrm{i}}$ were derived from the chemical shift of the inorganic phosphate resonance as previously described [11]. In some of the experiments we observed heterogeneity of the inorganic phosphate peaks during reperfusion. The averaged inorganic phosphate chemical shifts were therefore used to calculate $\mathrm{pH}_{\mathrm{i}}$.

\section{Experimental protocol}

The experimental protocol consisted of $15 \mathrm{~min}$ of control perfusion followed by $30 \mathrm{~min}$ of no-flow ischaemia and 40 min of reperfusion. In all study groups, except when otherwise mentioned, perfusate contained a similar free ionised $\mathrm{Ca}^{2+}$ concentration $(0.9 \mathrm{mmol} / \mathrm{l})$, adjusted by using $0.5 \mathrm{mmol} / 1$ EDTA when $\mathrm{Na}^{+}$shift agent was not used. In each group, diabetic or non-diabetic hearts either received or did not receive the NHE inhibitor cariporide $(1 \mu \mathrm{mol} / \mathrm{l}$; a gift from Aventis Pharma) [22]. When present, cariporide was added to the perfusion solution $10 \mathrm{~min}$ before inducing ischaemia and was present throughout.

Arrhythmia study

Unipolar ECG was recorded continuously on a Gould 2,200 recorder (Gould Instruments) from perfused hearts, using a reference electrode connected to the steel cannula and a silver electrode flanking the heart. Chart speed was set at $10 \mathrm{~mm} / \mathrm{s}$ during control perfusion and ischaemia. A few seconds before reperfusion, it was set at 25 or $50 \mathrm{~mm} / \mathrm{s}$

Table 1 Characteristics of control $(d b /+)$ and diabetic $(d b / d b)$ mice ( $n=9$ /group)

\begin{tabular}{lcc}
\hline & Control $d b /+$ & Diabetic $d b / d b$ \\
\hline Body weight $(\mathrm{g})$ & $28.1 \pm 0.4$ & $46.8 \pm 0.9^{*}$ \\
Heart dry weight $(\mathrm{mg})$ & $25.8 \pm 0.7$ & $25.6 \pm 0.2$ \\
Plasma glucose $(\mathrm{mmol} / \mathrm{l})$ & $12.5 \pm 0.8$ & $37.2 \pm 4.5^{*}$ \\
Plasma triglycerides $(\mathrm{mmol} / \mathrm{l})$ & $0.7 \pm 0.1$ & $1.9 \pm 0.2^{*}$ \\
\hline
\end{tabular}

Values are means \pm SEM. Plasma samples were collected from fed mice

*Significantly different from control

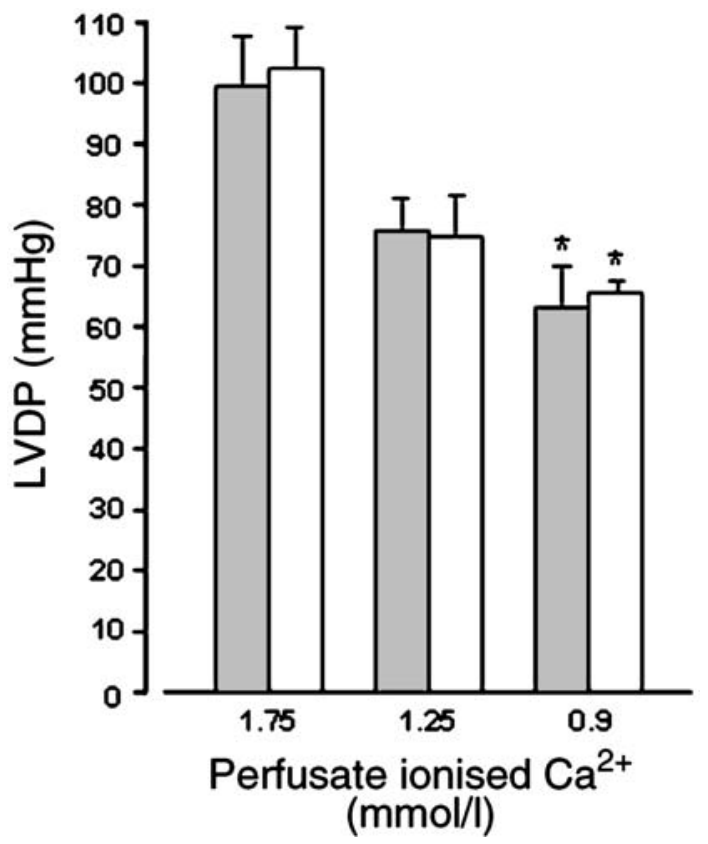

Fig. 1 Mean \pm SEM values of left ventricular developed pressure (LVDP) after $30 \mathrm{~min}$ of control perfusion with perfusate containing either 1.75 or $1.25 \mathrm{mmol} / 1(n=6 d b / d b$ and $d b /+$ hearts for each concentration) or $0.9 \mathrm{mmol} / \mathrm{l}(n=7 \mathrm{db} / \mathrm{db}$ and $d b /+$ hearts) ionised $\mathrm{Ca}^{2+} .{ }^{*} p<0.05$ vs $1.75 \mathrm{mmol} / \mathrm{l}$. Results from $d b / d b$ hearts, grey bars; results from $d b /+$ hearts, open bars

so as to obtain a permanent high-speed recording [23]. The ECG was retrospectively analysed, in a blind manner, for the incidence, time to onset, and duration of ventricular tachycardia (VT) and ventricular fibrillation (VF) during reperfusion. All analyses were carried out in accordance with the Lambeth Conventions [24]. VT was defined as four or more consecutive premature beats of ventricular

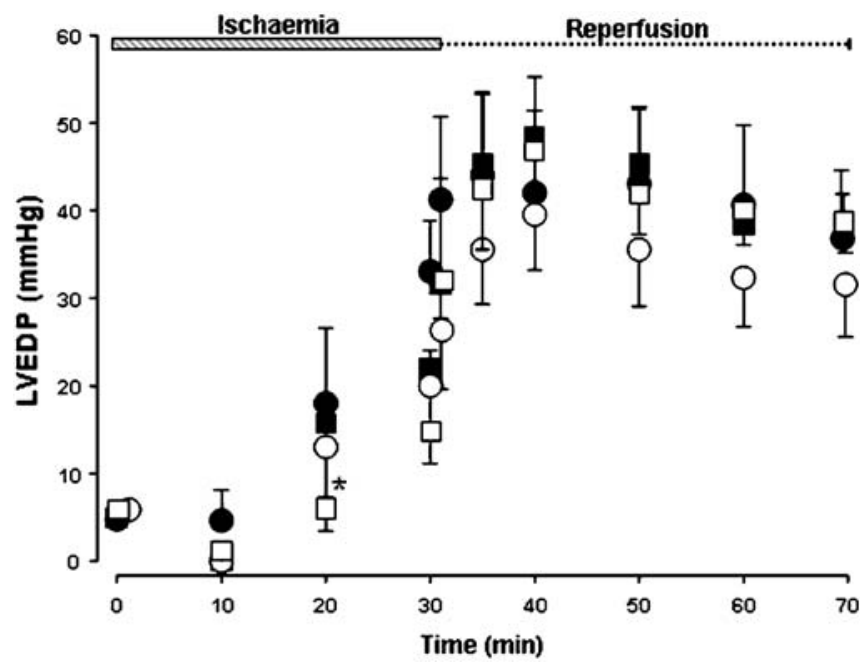

Fig. 2 Left ventricular end diastolic pressure (LVEDP) during ischaemia and reperfusion in isovolumic perfused hearts from nondiabetic $d b /+$ (solid circles) and diabetic $d b / d b$ male mice (solid boxes), and in hearts from $d b /+$ (open circles) and $d b / d b$ mice (open boxes) receiving cariporide. Means \pm SEM, $n=5$ hearts in each group. $* p<0.05$ for difference from $d b / d b$ hearts without cariporide 
origin, and VF was defined as a signal in which individual QRS deflections could no longer be distinguished from one another and for which the rate could not be determined.

Analysis of plasma metabolites

Blood samples (fed dietary status) were taken from the body cavity after excision of the heart. The blood was centrifuged in an Eppendorff centrifuge at $17,000 \mathrm{~g}$ and $4^{\circ} \mathrm{C}$ for $15 \mathrm{~min}$. The resulting plasma sample was stored at $-20^{\circ} \mathrm{C}$ before analysis. Plasma glucose and triglyceride levels were measured with kits from J2L Elitech (LabartheInard, France).
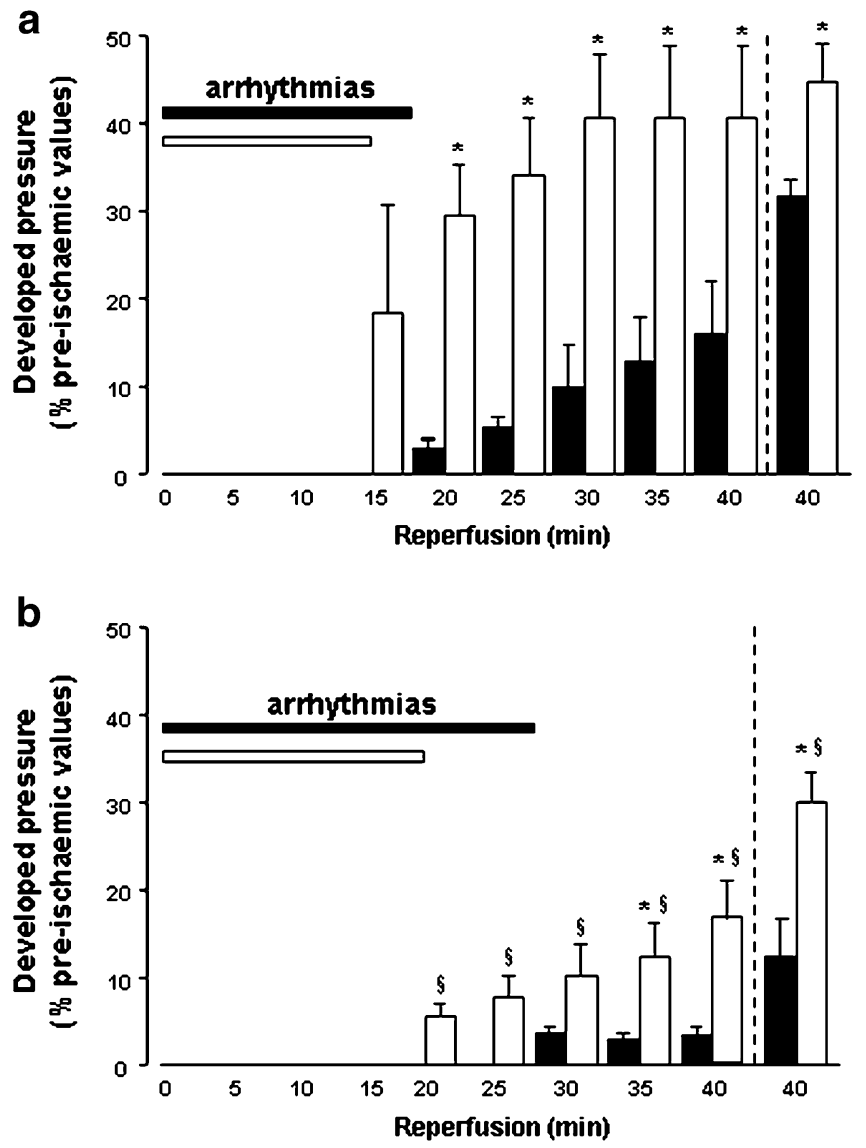

Fig. 3 LVDP during reperfusion following no-flow ischaemia. a Hearts from non-diabetic $d b /+$ mice receiving (open columns) or not receiving (filled columns) cariporide. b Hearts from diabetic $d b /$ $d b$ mice receiving (open columns) or not receiving (filled columns) cariporide. The horizontal bars indicate the time-period of occurrence of ventricular arrhythmias for the groups of hearts receiving (empty bars) or not receiving (filled bars) cariporide. Means \pm SEM, $n=5$ hearts in each group. The columns right of the dotted line $(\mathbf{a}, \mathbf{b})$ show recovery of developed pressure for $d b /+$ and $d b / d b$ hearts that received perfusate containing $1.75 \mathrm{mmol} / 1$ ionised $\mathrm{Ca}^{2+}\left(40_{1.75}\right)$ ${ }^{*} p<0.05$ for difference from hearts without cariporide. $\S p<0.05$ for difference from $d b /+$ hearts with cariporide
Statistical analysis

Results are presented as means \pm SEM. The data were analysed using either Student's $t$ test for unpaired data or ANOVA followed by the appropriate post hoc test to locate differences between groups. Binominally distributed variables, such as the incidence of VT or VF, were compared using the $\chi^{2}$ test for a $2 \times n$ table, followed by a sequence of $2 \times 2 \chi^{2}$ tests with Yates's correction. Significance was set at $p<0.05$.

\section{Results}

Animal characteristics

At $12-15$ weeks of age, diabetic $d b / d b$ mice weighed significantly more than their control non-diabetic $d b /+$ littermates (Table 1). This observation is in agreement with previous studies $[5,6]$. Heart weight was similar in both groups of mice. As expected [5], $d b / d b$ mice had significantly elevated plasma levels of glucose and triglyceride, reflecting their diabetic status with hyperglycaemia and hyperlipidaemia.

Ventricular function in hearts from $\mathrm{db} / \mathrm{db}$ mice

We first tested, in pilot experiments, the response of the hearts to standard perfusate buffer $\mathrm{Ca}^{2+}$ concentrations. LVDP measured after 30-min perfusion with nominally
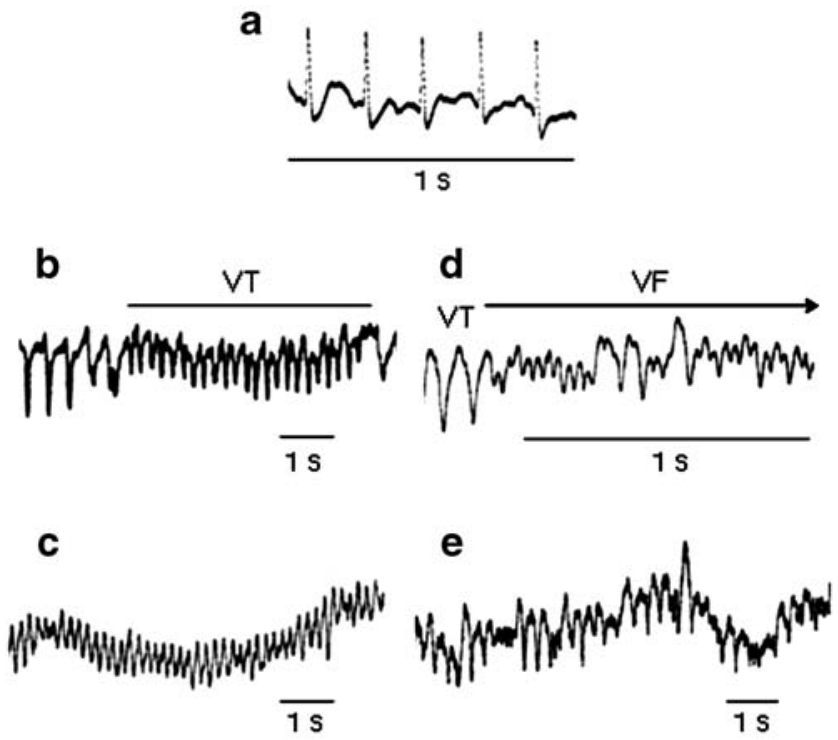

Fig. 4 Representative recordings of reperfusion-induced ventricular arrhythmias obtained from hearts of $d b / d b$ mice. a Normal sinus rhythm; b non-sustained VT; $\mathbf{c}$ sustained VT; $\mathbf{d}$ degeneration of VT into VF; e VF 
$2.0 \mathrm{mmol} / \mathrm{C} \mathrm{Ca}^{2+}$ (approximately $1.75 \mathrm{mmol} / \mathrm{l}$ ionised $\mathrm{Ca}^{2+}$ ) was in the range of values previously reported for the mouse heart under similar conditions $[25,26]$, with no difference between control and diabetic hearts (Fig. 1). Decreasing perfusate calcium from 1.75 to 1.25 and then to $0.9 \mathrm{mmol} / 1$ ionised $\mathrm{Ca}^{2+}$ decreased LVDP, as previously described [25, 26], again with no significant difference in hearts from diabetic mice compared with hearts from non-diabetic mice (Fig. 1). Nor was there any significant difference in coronary flow rate $(2.2 \pm 0.2, n=11$, and $2.4 \pm 0.2 \mathrm{ml} / \mathrm{min}$, $n=12$, in $d b /+$ and $d b / d b$ hearts, respectively) or heart rate ( $378 \pm 10, n=9$, and $352 \pm 10$ beats/min, $n=11$, in $d b /+$ and $d b /$ $d b$ hearts, respectively) between hearts from the two groups.

During ischaemia, LVDP rapidly decreased to zero for all groups whereas LVEDP increased. LVEDP increase (Fig. 2) was not significantly different between groups over the entire period of ischaemia except for a slightly smaller increase in the $d b / d b$ hearts in the presence of cariporide (only significant at $20 \mathrm{~min}$ of ischaemia, $p<0.05)$. There were no significant differences in LVEDP during reperfusion between $d b / d b$ and $d b /+$ hearts and between hearts in each group receiving or not receiving cariporide. Correct measurements of LVDP upon reperfusion were not possible at some time points over the first 15 $20 \mathrm{~min}$, depending on heart groups, due to the development of reperfusion-induced arrhythmias (Fig. 3a,b). Fig. 3a,b also shows that the percentage of LVDP recovery was significantly lower in $d b / d b$ hearts that did not receive cariporide than in in $d b /+$ hearts under similar perfusion conditions. Cariporide markedly improved the recovery of LVDP in $d b /+$ hearts, from $15-20 \mathrm{~min}$ to the end of reperfusion. Although to a lesser extent, a significant improvement in LVDP recovery was also observed in hearts from diabetic $d b / d b$ mice. We next examined whether the difference in functional recovery between cariporide-treated and untreated hearts would also be present at a more physiological calcium concentration. A group of hearts from both $d b /+$ and $d b / d b$ mice was perfused with buffer containing $1.75 \mathrm{mmol} / 1$ ionised $\mathrm{Ca}^{2+}$. Under these conditions, ventricular function recovery was higher than in the presence of $0.9 \mathrm{mmol} / 1$ ionised $\mathrm{Ca}^{2+}$. However, cariporide again significantly increased the recovery of LVDP in both diabetic and non-diabetic hearts, as shown in Fig. 3 at 40 min of reperfusion.
Fig. 5 Incidence (\%) and duration in seconds (s) of VT (a) and of VF (b) in hearts from diabetic $d b / d b$ and from non-diabetic $d b /+$ mice receiving or not receiving cariporide. Means \pm SEM, $n=5$ hearts in each group. $\# p<0.05$ vs $d b /+$ hearts; ${ }^{*} p<0.05$ vs without cariporide. s, seconds; $\%$, percentage of incidence
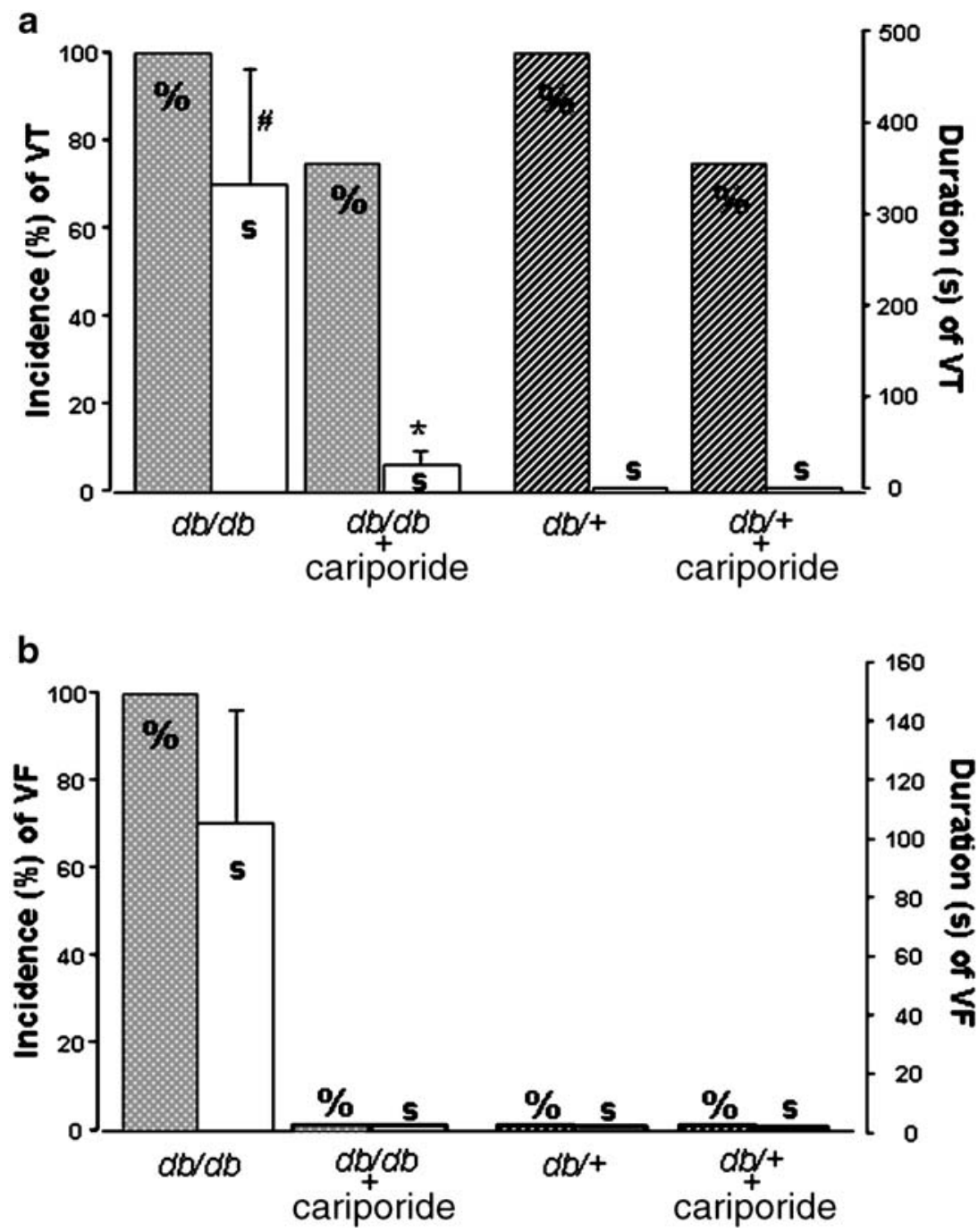
Reperfusion-induced arrhythmias

Reperfusion-induced arrhythmias (Fig. 4) occurred in all groups of hearts and all of them terminated spontaneously. The time-periods of occurrence of ventricular arrhythmias (from the earliest onset of arrhythmia to the latest end of arrhythmia in each group) were $15-1,635 \mathrm{~s}$ in $\mathrm{db} / \mathrm{db}$ vs 20 $1,121 \mathrm{~s}$ in $d b /+$ hearts without cariporide, whereas they were $30-1,116 \mathrm{~s}$ in $d b / d b$ and $30-882 \mathrm{~s}$ in $d b /+$ hearts, respectively, in the presence of cariporide (Fig. 3). Although the incidence of VT (Fig. 5a) was $100 \%$ in both $d b / d b$ and $d b /+$ hearts, duration of VT in $d b / d b$ hearts was significantly greater than in $d b /+$ hearts. Cariporide similarly decreased the incidence of VT (to 75\%) in both $d b / d b$ and $d b /+$ hearts. Duration of VT was also significantly reduced in $\mathrm{db} / \mathrm{d} b$ hearts in the presence of cariporide, but the short duration of VT in $d b /+$ hearts remained unchanged.

In all $d b / d b$ hearts, degeneration of VT into VF (Fig. 5b) was observed (100\% incidence). This did not occur in $\mathrm{db} /+$ hearts. No occurrence of VF was observed in any of the two groups of hearts receiving cariporide.

Changes in $\mathrm{Na}_{\mathrm{i}}^{+}$in hearts from $d b / d b$ mice

There were no differences in the mean values of $\mathrm{Na}_{\mathrm{i}}^{+}$ obtained from the ${ }^{23} \mathrm{Na}$ NMR spectra during control perfusion between $d b / d b(13.9 \pm 1.5 \mathrm{mmol} / 1, n=8)$ and $d b /+$ hearts $(14.2 \pm 0.7 \mathrm{mmol} / \mathrm{l}, n=8)$. These values were unchanged in hearts receiving cariporide $(15.2 \pm 1.9$ and $15.1 \pm$ $0.9 \mathrm{mmol} / \mathrm{l}$ for the $d b / d b$ and $d b /+$ hearts, respectively, $n=5$ hearts in each group). As shown in Fig. 6, $\mathrm{Na}_{i}^{+}$increased more rapidly during no-flow ischaemia in hearts from diabetic $d b / d b$ mice than in hearts from non-diabetic $d b /+$ mice, reaching $179.0 \pm 4.9 \%$ and $158.0 \pm 8.1 \%$ of control values at end ischaemia, respectively $(p<0.05)$. Hearts receiving cariporide showed a similar time course of $\mathrm{Na}_{i}^{+}$ increase to that observed in the absence of cariporide over the first $20 \mathrm{~min}$ of ischaemia. Although not significantly different, a tendency towards a lesser increase in $\mathrm{Na}_{\mathrm{i}}^{+}$was observed in the group of $d b /+$ hearts receiving cariporide. However, in both $d b / d b$ and $d b /+$ hearts, the presence of cariporide significantly reduced the rise in $\mathrm{Na}_{i}^{+}$at the end of ischaemia $(157.6 \pm 9.4 \%$ vs $179.0 \pm 4.9 \%$ in $\mathrm{db} / \mathrm{db}$ hearts and $126.2 \pm 10.9$ vs $158.0 \pm 8.1 \%$ in $d b /+$ hearts).

Changes in $\mathrm{pH}_{\mathrm{i}}$ in hearts from $d b / d b$ mice

Since the presence of the NHE inhibitor cariporide reduced the rise in $\mathrm{Na}_{i}^{+}$at the end of ischaemia and since NHE contributes significantly to the integrated control of $\mathrm{pH}_{\mathrm{i}}$ during ischaemia and reperfusion [15], we examined $\mathrm{pH}_{\mathrm{i}}$ during ischaemia and reperfusion. As shown in Fig. 7, the two main observations from this $\mathrm{pH}_{\mathrm{i}}$ investigation were: (1) cariporide significantly accentuated the decrease in $\mathrm{pH}_{\mathrm{i}}$ during ischaemia in diabetic hearts but not in non-diabetic hearts; and (2) the rate of $\mathrm{pH}_{\mathrm{i}}$ recovery was markedly increased over the first $25 \mathrm{~min}$ of reperfusion, particularly at the very beginning of reperfusion, in diabetic compared with non-diabetic hearts.
Fig. 6 Changes (mean percent of control values \pm SEM) in $\mathrm{Na}_{i}^{+}$ during $30 \mathrm{~min}$ of no-flow is chaemia in hearts from non-diabetic $d b /+$ (filled circles) and from diabetic $d b / d b$ mice (filled boxes) that did not receive cariporide, and in hearts from $d b /+$ (open circles) and $d b / d b$ (open boxes) mice that received cariporide. $n=8$ hearts per group without cariporide and $n=5$ hearts per group with cariporide. ${ }^{*} p<0.05$ vs without cariporide. Inset: ${ }^{23} \mathrm{Na}$ NMR spectra of isolated perfused mouse heart showing $\mathrm{Na}_{i}^{+}$increase during ischaemia. $\mathrm{Na}_{\mathrm{e}}$ is the extracellular peak shifted by TmDOTP $^{5-}$

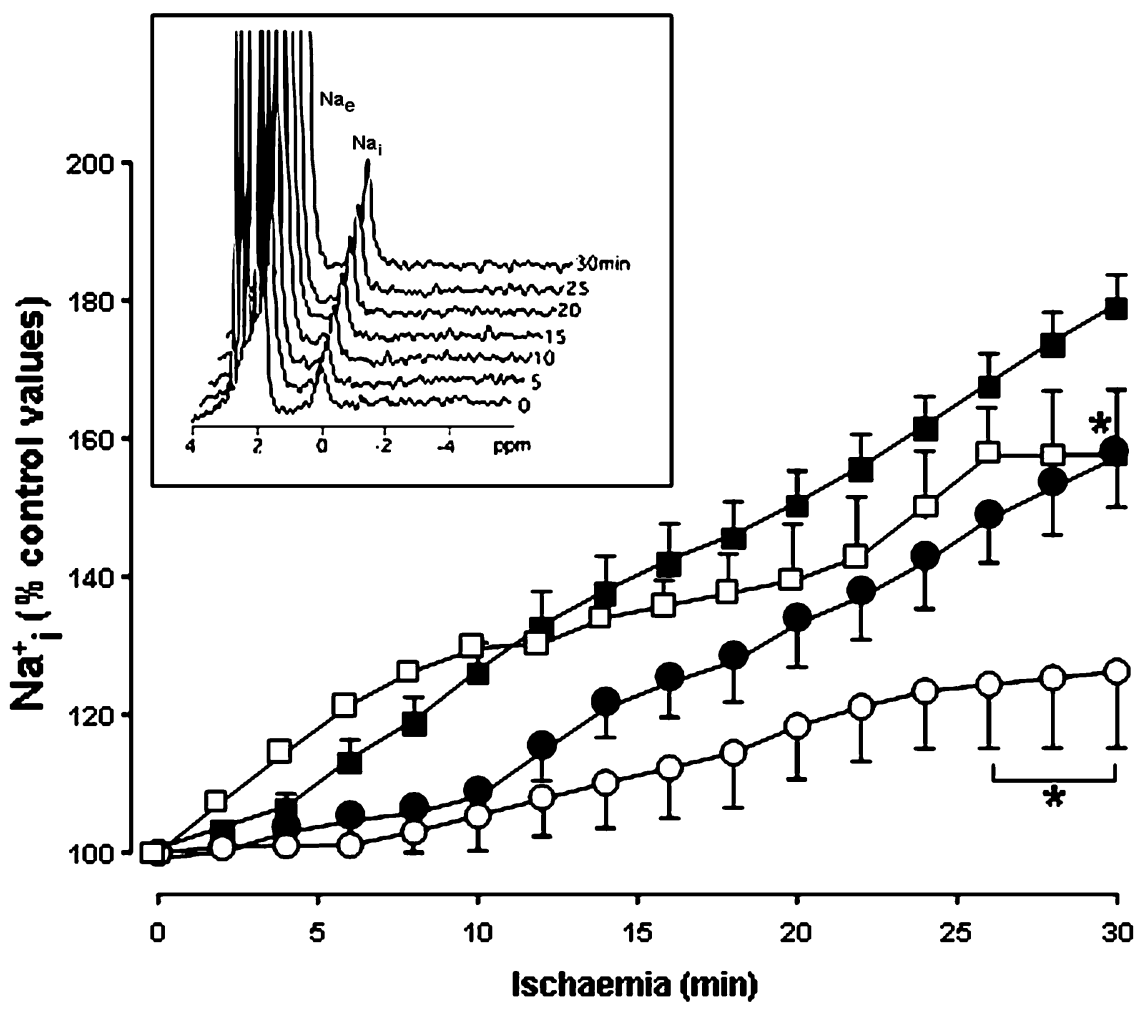



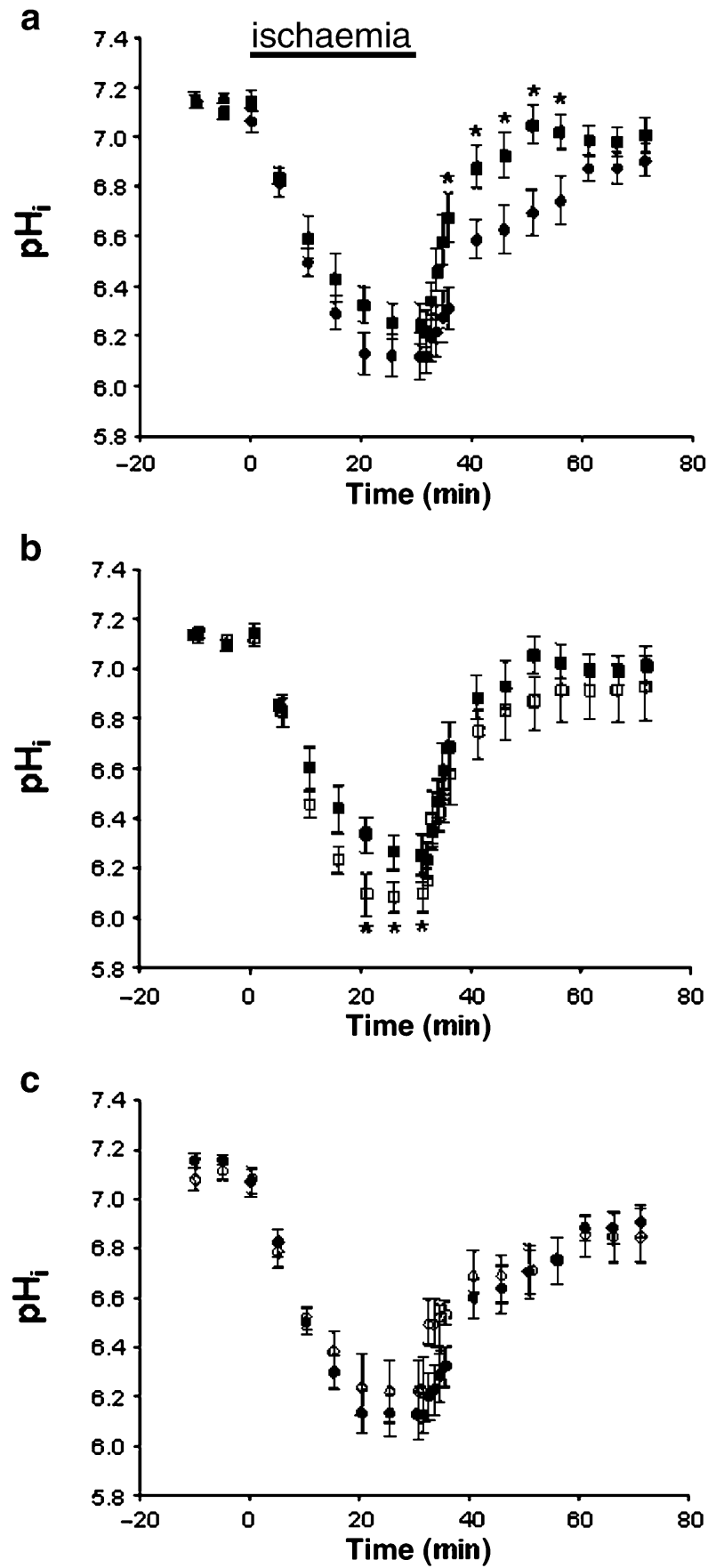

Fig. 7 Mean values \pm SEM of $\mathrm{pH}_{\mathrm{i}}$ during $30 \mathrm{~min}$ of no-flow ischaemia and reperfusion in a hearts from non-diabetic $\mathrm{db} /+$ (solid circles) and from diabetic $d b / d b$ mice (solid boxes) that did not receive cariporide, in $\mathbf{b}$ hearts from diabetic $d b / d b$ mice that received cariporide (open boxes), and $\mathbf{c}$ in hearts from non-diabetic $d b /+$ mice that received cariporide (open circles). ${ }^{*} p<0.05$ vs $d b /+$ (a); ${ }^{*} p<0.05$ vs $d b / d b$ without cariporide (b). $n=7 d b / d b$ with or without cariporide, $n=6 \mathrm{db} /+$ with or without cariporide

\section{Discussion}

The main feature of this study was that increased susceptibility to ischaemia-reperfusion in $d b / d b$ hearts mainly consisted of a higher duration of VT and the degeneration of VT into VF upon reperfusion after global ischaemia.
This was associated with delayed and lower levels of recovery of developed pressure. It could be argued that the relatively low level of ionised $\mathrm{Ca}^{2+}$ used in the present work may have affected the functional response of the hearts to ischaemia and reperfusion injury, as well as the response to cariporide treatment. LVDP recovery was indeed higher in hearts perfused with a more physiological $\mathrm{Ca}^{2+}$ concentration, i.e. $1.75 \mathrm{mmol} / \mathrm{l}$ vs $0.9 \mathrm{mmol} / \mathrm{l}$. However, the comparison of LVDP recovery after $40 \mathrm{~min}$ of reperfusion in the presence and absence of cariporide in each of the two groups of mouse hearts clearly showed a beneficial effect of cariporide $(30.0 \pm 3.4 \%$ of the preischaemic level vs $12.1 \pm 4.3 \%$ in the absence of cariporide for the $d b / d b, p=0.012$, and $44.6 \pm 4.3$ vs $31.6 \pm 1.8 \%$, $p=0.023$, for the $d b /+$ hearts). In the only previous report on ischaemic sensitivity in hearts from $d b / d b$ mice, perfused working hearts demonstrated decreased postischaemic recovery of coronary flow compared with control hearts, and because coronary flow is an important determinant of cardiac function the decreased postischaemic function could also reflect impaired flow as a result of vascular or endothelial dysfunction in addition to myocyte dysfunction. No such difference was observed in the present work, since coronary flow recovery after $5 \mathrm{~min}$ of reperfusion averaged $71 \%(1.57 \pm 0.15 \mathrm{ml} / \mathrm{min}, n=11)$ and $73.8 \%(1.77 \pm 0.26 \mathrm{ml} / \mathrm{min}, n=12)$ in $d b /+$ and $d b / d b$ hearts, respectively. In the above mentioned study, treatment aimed at normalising metabolic disturbances (with an activator of peroxisome proliferator-activated receptor- $\alpha$ ) failed to improve mechanical recovery after ischaemiareperfusion, even though carbohydrate oxidation was stimulated and palmitate oxidation was decreased. This finding suggested that in the severe type 2 diabetic $d b / d b$ mice, at least not all the adverse effects of diabetes on the recovery of contractile function after ischaemia-reperfusion were due to altered metabolism [6].

An important determinant of sensitivity to ischaemiareperfusion is altered ion homeostasis, especially disturbances in $\mathrm{Na}_{\mathrm{i}}^{+}$handling $[11,12]$. This study is the first to demonstrate that myocardial $\mathrm{Na}_{\mathrm{i}}^{+}$increased substantially in isolated mouse hearts during ischaemia and increased significantly more in hearts from diabetic $d b / d b$ hearts than in hearts from control $d b /+$ mice. In this context, the present $\mathrm{pH}_{\mathrm{i}}$ data are of particular interest. Indeed, Fig. 7a shows a trend towards a lesser $\mathrm{pH}_{\mathrm{i}}$ decrease during the last $10 \mathrm{~min}$ of ischaemia in $d b / d b$ hearts, although the differences observed between $\mathrm{pH}_{\mathrm{i}}$ values of these hearts and those of $d b /+$ mice over the same period were not significant. The accentuated $\mathrm{pH}_{\mathrm{i}}$ decrease in cariporide-treated $d b / d b$ hearts over this same period of ischaemia (Fig. 7b) seems to indicate that NHE was not totally inhibited in diabetic hearts. No information is available to date concerning NHE activity in type 2 diabetic $d b / d b$ mouse hearts. In streptozotocin-induced diabetic rats, we previously reported a $\sim 50 \%$ increase in levels of $\mathrm{Na}_{i}^{+}$at baseline [27], these results being consistent with a decrease in NHE activity in this model [28]. No such increase was found here in $d b / d b$ hearts. We can therefore infer from these data and from the 
$\mathrm{pH}_{\mathrm{i}}$ data that NHE activity would at least not be decreased in type 2 diabetic $d b / d b$ mouse hearts. Consistent with the $\mathrm{pH}_{\mathrm{i}}$ data in $d b / d b$ hearts, this study also shows that the NHE inhibitor cariporide significantly reduced the rise in $\mathrm{Na}_{\mathrm{i}}^{+}$at end ischaemia. However, and surprisingly, this effect appeared less pronounced in diabetic $(-21 \%)$ than in control $(-31 \%)$ hearts. This apparent contradistinction could be explained if $\mathrm{Na}^{+}$influx during ischaemia also occurs via other routes than NHE, which may be $\mathrm{Na}^{+}$/ $\mathrm{HCO}_{3}^{-}$cotransport [29] and the voltage-gated $\mathrm{Na}^{+}$channel, especially a slowly inactivating component of $\mathrm{Na}^{+}$current $\left(I_{\mathrm{NaL}}\right)[17,21,30,31]$. We have previously shown that such a current is partially inhibited by known NHE blockers and also reduced in diabetic rat hearts [30]. Since the $d b / d b$ hearts show an increased $\mathrm{Na}_{\mathrm{i}}^{+}$accumulation, this must therefore result from NHE- and/or $\mathrm{Na}^{+} / \mathrm{HCO}_{3}^{-}$cotransportmediated $\mathrm{Na}^{+}$influx. More $\mathrm{Na}^{+}$influx means more acidequivalent efflux. Because $\mathrm{pH}_{\mathrm{i}}$ at the end of ischaemia shows no significant difference between $d b / d b$ and $d b /+$ hearts, we can envisage two possibilities: (1) there is a higher ischaemic proton production in the $d b / d b$ hearts; and/or (2) the intracellular $\mathrm{H}^{+}$buffering capacity is decreased. The cariporide-sensitive $\mathrm{Na}^{+}$influx during ischaemia in control hearts may have resulted not only from inhibition of NHE, but also from some degree of cariporide-induced inhibition of $I_{\mathrm{NaL}}$, the latter being reduced in diabetic hearts. Nevertheless, cariporide treatment was associated with a similar lower incidence of VT in both groups of hearts but with a markedly shorter duration of VT in diabetic $d b / d b$ hearts. Moreover, the most prominent effect of cariporide was that it totally inhibited the degeneration of VT into VF in $d b / d b$ hearts, the incidence of which was $100 \%$ without cariporide, whereas none of the $d b /+$ hearts exhibited VF. In this regard, $\mathrm{Na}_{\mathrm{i}}^{+}$ accumulation has been shown by others to be a strong predictor of VF [32]. Of particular interest is our observation of a high incidence of VF in diabetic $d b / d b$ hearts with exacerbated ischaemia-induced $\mathrm{Na}_{i}^{+}$increase. It is known that increases in $\mathrm{Na}_{i}^{+}$in ischaemic cardiomyocytes generate $\mathrm{Ca}^{2+}$ loading via reverse $\mathrm{Na}^{+} / \mathrm{Ca}^{2+}$ exchange, which mediates much of the damage incurred upon reperfusion [33, 34]. Since diabetic $d b / d b$ mouse hearts have a deficiency in cardiomyocyte $\mathrm{Ca}^{2+}$ handling, in particular an increased $\mathrm{Ca}^{2+}$ leakage from the sarcoplasmic reticulum, as recently shown by Belke et al. [35], this may in turn precipitate the occurrence of ventricular arrhythmias [36]. Our data indicate that reducing accumulation of $\mathrm{Na}_{\mathrm{i}}^{+}$ to a modest extent may indeed have marked beneficial effects on the occurrence of VF and on ventricular function.

It has also previously been shown that one factor promoting degeneration of VT into VF during early reperfusion is the rate at which extracellular $\mathrm{pH}$ is restored [23] and extracellular $\mathrm{pH}$ restoration influences $\mathrm{pH}_{\mathrm{i}}$ [37]. We report here a markedly higher recovery rate of $\mathrm{pH}_{\mathrm{i}}$ in $d b / d b$ hearts during reperfusion, with an abrupt slope over the first $5 \mathrm{~min}$, compared with $d b /+$ hearts. However, since this $\mathrm{pH}_{\mathrm{i}}$ recovery rate on reperfusion was not influenced by cariporide in either $d b /+$ or $d b / d b$ hearts, this seems to exclude the possibility of $\mathrm{pH}_{\mathrm{i}}$ recovery rate playing a significant role in the development of VF, which was highly cariporide-sensitive in $d b / d b$ hearts. Therefore, the rapid rise of $\mathrm{pH}_{\mathrm{i}}$ on reperfusion, which has been shown to be mediated principally by metabolite washout (lactate and $\mathrm{CO}_{2}$ ) over the first 2-3 min and also by $\mathrm{Na}^{+} / \mathrm{HCO}_{3}^{-}$ cotransport [38-40], may suggest changes in the activity of these mechanisms in $d b / d b$ hearts.

\section{Conclusion}

In this study we found that hearts from $d b / d b$ mice had enhanced susceptibility to cardiac ischaemia, associated with a higher rise in $\mathrm{Na}_{\mathrm{i}}^{+}$. The data also suggest a higher sensitivity of $d b / d b$ hearts to the protective effect of cariporide, as assessed particularly by the marked inhibition of the degeneration of VT into VF upon reperfusion. It must be acknowledged that data obtained with the use of a leptin-signalling-deficient model to represent type 2 diabetes should be interpreted with caution. In view of emerging evidence for cardiac effects of leptin and that leptin may represent an autocrine/paracrine regulator of cardiac function [41], future work will have to examine the possible interplay between leptin-signalling pathway(s) and $\mathrm{Na}_{\mathrm{i}}^{+}$-regulating mechanisms, especially NHE.

Acknowledgements This study was supported by a grant from Fondation de France and by an Action Concertée Incitative 'Plateformes d'explorations fonctionnelles thématisées 2003'.

\section{References}

1. Devereux RB, Roman MJ, Paranicas M et al (2000) Impact of diabetes on cardiac structure and function. The Strong Heart Study. Circulation 101:2271-2276

2. Shehadeh A, Regan TJ (1995) Cardiac consequences of diabetes mellitus. Clin Cardiol 18:301-305

3. Frustaci A, Kajstura J, Chimenti C et al (2000) Myocardial cell death in human diabetes. Circ Res 87:1123-1132

4. Maddaford TG, Russell JC, Pierce GN (1997) Postischemic cardiac performance in the insulin-resistant JCR:LA-cp rat. Am J Physiol Heart Circ Physiol 42:H1187-H1192

5. Belke DD, Larsen TJ, Gibbs EM, Severson DL (2000) Altered metabolism causes cardiac dysfunction in perfused hearts from diabetic $(d b / d b)$ mice. Am J Physiol Endocrin Metab 279: E1104-E1113

6. Aasum E, Hafstad AD, Severson DL, Larsen TS (2003) Agedependent changes in metabolism, contractile function, and ischemic sensitivity in hearts from $d b / d b$ mice. Diabetes $52: 434-441$

7. Leibel RL, Chung WK, Chua SR Jr (1997) The molecular genetics of rodent single gene obesities. J Biol Chem 272:31937-31940

8. Wyse BM, Dulin WE (1970) The influence of age and dietary conditions on diabetes in the $d b$ mouse. Diabetologia 6:268273

9. Cavaghan MK, Ehrmann DA, Polonsky KS (2000) Interactions between insulin resistance and insulin secretion in the development of glucose intolerance. J Clin Invest 106:329-333 
10. Semeniuk LM, Kryski AJ, Severson DL (2002) Echocardiographic assessment of cardiac function in diabetic $d b / d b$ and transgenic $d b / d b$-hGLUT4 mice. Am J Physiol Heart Circ Physiol 283:H976-H982

11. El Banani H, Bernard M, Baetz D et al (2000) Changes in intracellular sodium and $\mathrm{pH}$ during ischaemia-reperfusion are attenuated by trimetazidine. Comparison between low- and zero-flow ischaemia. Cardiovasc Res 47:688-696

12. Imahashi K, Kusuoka H, Hashimoto K, Yoshioka J, Yamaguchi H, Nishimura T (1999) Intracellular sodium accumulation during ischemia as the substrate for reperfusion injury. Circ Res 84:1401-1406

13. Pogwizd SM, Sipido KR, Verdonck F, Bers DM (2003) Intracellular $\mathrm{Na}$ in animal models of hypertrophy and heart failure: contractile function and arrhythmogenesis. Cardiovasc Res 57:887-896

14. Khandoudi N, Bernard M, Cozzone P, Feuvray D (1990) Intracellular $\mathrm{pH}$ and role of $\mathrm{Na}^{+} / \mathrm{H}^{+}$exchange during ischaemia and reperfusion of normal and diabetic rat hearts. Cardiovasc Res 24:873-878

15. Feuvray D (1997) The regulation of intracellular $\mathrm{pH}$ in the diabetic myocardium. Cardiovasc Res 34:48-54

16. Hartmann M, Decking UKM (1999) Blocking $\mathrm{Na}^{+}-\mathrm{H}^{+}$exchange by cariporide reduces $\mathrm{Na}^{+}$overload in ischemia and is cardioprotective. J Mol Cell Cardiol 31:1985-1995

17. Baetz D, Bernard M, Pinet C et al (2003) Different pathways for sodium entry in cardiac cells during ischemia and early reperfusion. Mol Cell Biochem 242:115-120

18. Anzawa R, Bernard M, Baetz D, Confort-Gouny S, Gascard JP, Feuvray D (2003) Increased susceptibility to ischaemiareperfusion of hearts from diabetic $(\mathrm{db} / \mathrm{db})$ mice: a functional and ${ }^{23} \mathrm{Na}$ NMR spectroscopy study. Eur J Heart Fail 2:17 (Abstract)

19. Pijnappel WWF, Van den Boogart, De Beer R, Van Ormondt D (1992) SVD-based quantification of magnetic resonance signals. J Magn Reson 97:122-134

20. Vanhamme L, Van den Boogart A, Van Huffel S (1997) Improved method for accurate and efficient quantification of MRS data with use of prior knowledge. J Magn Reson 129:3543

21. Van Emous JG, Nederhoff MGJ, Ruigrok TJC, Van Echteld CJA (1997) The role of the $\mathrm{Na}^{+}$channel in the accumulation of intracellular $\mathrm{Na}^{+}$during myocardial ischemia: consequences for post-ischemic recovery. J Mol Cell Cardiol 29:85-96

22. Scholz W, Albus U, Counillon L et al (1995) Protective effect of HOE 642, a selective sodium-hydrogen exchange subtype 1 inhibitor, on cardiac ischaemia and reperfusion. Cardiovasc Res 29:260-268

23. Avkiran M, Ibuki C (1992) Reperfusion-induced arrhythmias. A role for washout of extracellular protons? Circ Res 71:14291440

24. Walker MJA, Curtis MJ, Hearse DJ et al (1988) The Lambeth Conventions: guidelines for the study of arrhythmias in ischemia, infarction, and reperfusion. Cardiovasc Res 22:447455

25. Brooks WW, Conrad CH (1999) Differences between mouse and rat myocardial contractile responsiveness to calcium. Comp Biochem Physiol A Mol Integr Physiol 124:139-147
26. Headrick JP, Peart J, Hack B, Garnham B, Matherne GP (2001) 5 '-adenosine monophosphate and adenosine metabolism, and adenosine responses in mouse, rat and guinea-pig heart. Comp Biochem Physiol A Mol Integr Physiol 130:615-631

27. Lagadic-Gossmann D, Feuvray D (1991) Intracellular sodium activity in papillary muscle from diabetic rat hearts. Exp Physiol 76:147-149

28. Le Prigent K, Lagadic-Gossmann D, Feuvray D (1997) Modulation by $\mathrm{pH}_{\mathrm{o}}$ and intracellular $\mathrm{Ca}^{2+}$ of $\mathrm{Na}^{+}-\mathrm{H}^{+}$exchange in diabetic rat isolated ventricular myocytes. Circ Res 80:253260

29. Ten Hove M, Nederhoff MG, Van Echteld CJ (2005) Relative contributions of $\mathrm{Na}^{+} / \mathrm{H}^{+}$exchange and $\mathrm{Na}^{+} / \mathrm{HCO}_{3}^{-}$cotransport to ischemic $\mathrm{Na}_{i}^{+}$overload in isolated rat hearts. Am J Physiol Heart Circ Physiol 288:H287-H292

30. Chattou S, Coulombe A, Diacono J, Le Grand B, John G, Feuvray D (2000) Slowly inactivating component of sodium current in ventricular myocytes is decreased by diabetes and partially inhibited by known $\mathrm{Na}^{+}-\mathrm{H}^{+}$exchange blockers. J Mol Cell Cardiol 32:1181-1192

31. Pinet C, Le Grand B, John GW, Coulombe A (2002) Thrombin facilitation of voltage-gated sodium channel activation in human cardiomyocytes. Implications for ischemic sodium loading. Circulation 106:2098-2103

32. Neubauer S, Newell JB, Ingwall JS (1992) Metabolic consequences and predictability of ventricular fibrillation in hypoxia. ${ }^{31} \mathrm{P}$ - and ${ }^{23} \mathrm{Na}$-nuclear magnetic resonance study of the isolated rat heart. Circulation 86:302-310

33. Tani M, Neely JR (1989) Role of intracellular $\mathrm{Na}^{+}$in $\mathrm{Ca}^{2+}$ overload and depressed recovery of ventricular function of reperfused ischemic rat hearts. Circ Res 65:1045-1056

34. Pogwizd SM, Schlotthauer K, Li L, Yuan W, Bers DM (2001) Arrhythmogenesis and contractile dysfunction in heart failure: roles of sodium-calcium exchange, inward rectifier potassium current, and residual beta-adrenergic responsiveness. Circ Res 88:1159-1167

35. Belke DD, Swanson EA, Dillmann WH (2004) Decreased sarcoplasmic reticulum activity and contractility in diabetic $d b$ / $d b$ mouse heart. Diabetes 53:3201-3208

36. Wehrens XHT, Lehnart SE, Huang F et al (2003) FKBP12.6 deficiency and defective calcium release channel (ryanodine receptor) function linked to exercise-induced sudden cardiac death. Cell 113:829-840

37. Vaughan-Jones RD, Wu M-L (1990) Extracellular $\mathrm{H}^{+}$inactivation of $\mathrm{Na}^{+}-\mathrm{H}^{+}$exchange in the sheep cardiac Purkinje fibre. J Physiol (Lond) 428:441-466

38. Vandenberg JI, Metcalfe JC, Grace AA (1993) Mechanisms of $\mathrm{pH}_{\mathrm{i}}$ recovery after global ischemia in the perfused heart. Circ Res 72:993-1003

39. Khandoudi N, Bernard M, Cozzone PJ, Feuvray D (1995) Mechanisms of intracellular $\mathrm{pH}$ regulation during postischemic reperfusion of diabetic rat hearts. Diabetes 44:196-202

40. Baetz D, Haworth RS, Avkiran M, Feuvray D (2002) The ERK pathway regulates $\mathrm{Na}^{+}-\mathrm{HCO}_{3}^{-}$cotransport activity in adult rat cardiomyocytes. Am J Physiol Heart Circ Physiol 283:H2102H2109

41. Purdham DM, Zou MX, Rajapurohitam V, Karmazyn M (2004) Rat heart is a site of leptin production and action. Am J Physiol Heart Circ Physiol 287:H2877-H2884 